\title{
ETHNOCULTURAL ASPECT OF THE UKRAINIAN AND ENGLISH PAROEMIAS WITH THE COMPONENT БОЛОТО/SWАМР
}

\author{
Savchenko O. O., \\ Ukraine, Drohobych, Drohobych I. Franko State Pedagogical University
}

DOI: https://doi.org/10.31435/rsglobal_wos/31082019/6659

\section{ARTICLE INFO}

Received: 25 June 2019

Accepted: 16 August 2019

Published: 31 August 2019

\section{KEYWORDS}

paroemia, concept, cognitive features, seme, verbalize, metaphoric meaning.

ABSTRACT

The article presents a comparative research of the Ukrainian and English paroemias with the lexemes denoting "marshy land" in their structure. It deals with similarities and differences of the component болото/swamp in definitions and synonymous names based on the Ukrainian and English languages. Besides, additional literal and metaphoric meanings of the above mentioned lexemes in the paremiological corpus of the compared languages have been revealed. A historical and cultural survey of the role this water-body played in the life of ancient Ukrainians and Britons has been given.
\end{abstract}

Citation: Savchenko O. O. (2019) Ethnocultural Aspect of the Ukrainian and English Paroemias with the Component Болото/Swamp. International Academy Journal Web of Scholar. 8(38), Vol.2. doi: 10.31435/rsglobal_wos/31082019/6659

Copyright: (C) 2019 Savchenko O. O. This is an open-access article distributed under the terms of the Creative Commons Attribution License (CC BY). The use, distribution or reproduction in other forums is permitted, provided the original author(s) or licensor are credited and that the original publication in this journal is cited, in accordance with accepted academic practice. No use, distribution or reproduction is permitted which does not comply with these terms.

Introduction. There have been numerous studies of the paroemias and their semantic content both in the Ukrainian and English languages. But no analysis has been carried out in terms of the ethnocultural aspect of proverbs and sayings with the lexical components denoting elements of relief within their structure. Such a research sheds light on the specifics of ethnoculture of ancient Ukrainians and Britons. Ethnic culture is a culture, originated from the collective art of a certain ethnic community. As part of culture it includes lifestyle, world outlook, language, folklore [1]. Therefore, the term "ethnoculture" relates to the way of life, religious beliefs, customs and traditions, values, views etc. As to the notion "paroemia", it is a laconic genre, which in the figurative form reflects the most essential phenomena and surrounding reality. Paroemias comprise proverbs, sayings and their genre varieties - riddles, greetings, well-wishes, curses, superstitions, comparisons, pun etc [2].

Research results. The lexeme "болото" in the Ukrainian lexicographic resources denotes: 1) a spongy place with excessively saturated soil, often with stagnant water and moisture-loving vegetation; 2) sing. A rarefied earth on the roads, paths and other routes due to the precipitation; mud; 3 ) sing. used figuratively, everything associated with mud, stagnation, lack of activity and initiative [3]. This word-unit functions in the same meaning in the Ukrainian paroemias, which is observed in the following instances: 1) Аби болото, а жаби будуть; 2) Годі з болота паску спечи; 3) Показує дорогу, а сам в болото лізе. In the latter the word "болото" figuratively actualizes the seme of immorality, wrong behavior, unhealthy lifestyle, i.e. this metaphoric denotative meaning of the analyzed name coincides with the transferred meaning, objectivized in the above-mentioned paroemia. It should be noted that in a number of the Ukrainian paroemias it is not a simple matter to differentiate the seme of a landscape object (marshland) from the seme of substance (mud): Не то кінь, щя в болото увезе, а то шо з болота вивезе.

The lexeme "болото" in the English language has numerous equivalents, namely swamp, bog, marshland, morass, bottoms, fens, glade, mud, marsh, mire, moor, polder, swale. All of them except "mud" denote swampy locality, i.e. an element of relief, but there are certain semantic differences 
between them. Let us consider the definitions of the words in question which verbalize the concept "swamp" in the English proverbial corpus. It must be pointed out that the variability in the use of names for a swampy area doesn't affect the actual meaning of a paroemia. Thus, a swamp means "an area of low-lying land that is frequently flooded, especially one dominated by woody plants, saturated with water". A marsh denotes "low-lying wet land with grassy vegetation". A bog designates "wet spongy ground consisting of decomposing vegetation, which ultimately forms peat". A fen relates to "low-lying wet land with grassy vegetation" [4]. Taking into account the above-mentioned definitions, it can be stated the synonymous series of the word "swamp" mainly expresses the direct meaning "an element of relief". As to the Ukrainian language, synonyms for the word "болото" are as follows: a) with the seme "spongy place with stagnant water": багно, багнище, мочарі мн. (одн. мочар), баговиння, багнюка, багновище, твань, тванюка; гниловоддя, моква, драговина, трясовина; b) with the seme "muddy ground": грязюка, багнюка, твань, тванюка, бруд, багно. Therefore, the synonymous series of the lexeme "болото" is productive too. However, there are particular stylistic and semantic differences between these synonyms, which is connected with geoclimatic peculiarities, ethnic heterogeneity of the territories inhabited by the representatives of the Ukrainian community. The evidence of this is the occurrence of dialect words for swampy locality. Thus, we can conclude that the English lexico-semantic variants of the analyzed word denote an element of relief, whereas the vast majority of the Ukrainian names for swampy land express both the first and the second direct meaning of the lexeme "болото".

Swamps played a significant role in the life of the ancient and medieval people, as they gave protection from sudden attacks of their enemies. Correspondingly, this safe location ensured quite stable development of crafts and farming. Apart from that, marshy territories acted as "providers". Owing to their rich vegetation they used to function as an ideal location for grazing cattle. Moreover, by means of melioration they turned into effective land, used for agricultural purposes. Swamps also attracted hunters and fishermen. From the 7th century BC until the 17th century AD swamps were sources of ore mining, which contributed to iron production. Historical chronicles and archeological findings testify to the fact that the old cities were situated on the marshy land, namely Kyiv and London. In ancient times London used to be a wild and deserted place with a few isles around it. The first documentary reference to London dates back to the times when in place of Westminster there was an unsurpassable swamp. Kyiv as the capital of Kyiv Rus was also founded on the so-called location "Goat's Swamp". Today this area is the main square of Kyiv - Maydan Nezalezhnosti (Independence Square). Not only particular cities, but also other historical regions were characterized by swampy landscape. In Ukraine it was Velykyi Luh (Great Meadow). Great Meadow is a historical name for the part of Ukraine which existed on the left bank of the Dnieper and presented itself as giant floating marshes. These are flooded or marshy areas of rivers close to the river deltas, overgrown with woods and reed. This historic area belonged to Zaporizhian Sich. On this site the Cossacks pastured their cattle and took a good shelter in its marshy meadows. The topic "swamp" is also represented in the names for ethnoses, inhabiting Ukraine. For example, the name Drehovychi, denoting one of the East Slavic tribes, was derived from the word "driahva". Besides, swamps played an essential role both in the culture and mythology of the Celts. It was in the swamps they would bring sacrifices to their gods.

The proverbial fund of the Ukrainian and English languages reveals additional cognitive features and constituents of the concept "boloto/swamp", verbalized by proverbs, sayings and riddles, which incorporate the names of the water-body under study. First, it should be pointed out that the concept "swamp" is not verbalized in the English paroemias, as we can hardly find any English proverbs and sayings with the component swamp and its synonyms in the English-speaking layer of folk wisdom. In contrast to the English folklore, the Ukrainian paremiological corpus comprises a great number of folk utterances with the lexeme "болото" in their structure.

The common cognitive features, elicited in the process of the paroemia analysis, extend the conceptual component of the researched concept in the compared languages: a) the habitat of certain species of birds and amphibians: Ходить як журавель по болоті; Кожна жаба своє болото хвалить; The frog cannot out of her bog; When you are up to your neck in alligators, it's easy to forget that the goal was to drain the swamp; b) in the Ukrainian paroemias mud is a favourite place for such domestic animals as pigs and horses: Свиню легше вигнати з болота, ніж ледаря на роботу; Журиться, як кобила, звернувши в болото; while according to the English ones a marsh is a habitat of hares and moors lure stray cows: As mad as a marsh hare; It is a bare moor that he goes over and gets not a cow. 
The distinctive meanings of the component "болото" are as follows: a) sponginess, the property to draw in: Гріх, що болото: чим далі, то все грузніше; b) the place difficult or even impossible to get out of, particularly without somebody's help: В болото влізти легко, а назад хоть воли впрягай; c) the place which engulfs everything which gets into it: Кинув як у болото; d) invaluable substance (mud): 3 болота паски не спечеш; e) having unpleasant smell: Не рушай болота, то не буде смердіти; f) being of dark colour: Злото і в болоті блищить; g) its occurrence in each populated area: Нема ні села, ні міста без болота; h) sometimes a source of a river: Насміялась річка болоту, а сама з болота витікає; i) a place of gold mining: За злото не єден лізе в болото.

According to the beliefs of the Slavs, in particular those of ancient Ukrainians, a swamp was a demonic locus, a dangerous and impure place inhabited by devils. In addition, a stable association of a devil with a swamp is expressed in the lexeme "нетеча", which stands for "swamp" as well as "devil". The convincing proof of demonic mythological and Christian conceptions of a swamp by the representatives of the Ukrainian ethnos is a wide range of proverbs and sayings: В болоті не без чорта; Чорт багато грошей має, а в болоті сидить; Править мов чорт болотом еtс.

The figurative constituent of the concept "болото", represented in Ukrainian paroemias is diverse and characterized by extremely negative connotations. The component болото in verbphrases, which actualize the seme "movement", functions as a symbol of trouble, misfortune, unfavourable life circumstances: Він і не вилазит з болота; Допоміг йому з калюжі в болото. In the English paremiological world image marshy land is perceived as troubles, life difficulties, objectivized by the following idioms: to leave in the mire, a dun in the mire. The latter figuratively refers to "misfortune".

In Ukrainian proverbs a swamp is opposed to water, as a bad person contrasts with a good one: Не сміється вода з болота, лиш болото з води. The figurative connotation "an evil person" is also realized by the lexeme "болото" in combination with other components in the paroemia: Не рушай болото - то не буде смердіти.

Not only water represents a highly moral person, but also gold does: Золото $i$ в болоті блищить, which is rendered like "A kind or talented person exhibits his or her virtues even under the worst circumstances".

In the paroemia У тихому болоті чорти водяться by means of metaphoric transference the image of a quiet swamp becomes the characteristics of an outwardly calm and humble person who can behave insidiously and do bad actions.

There are numerous paroemias, where a swamp is a locus, in which material things vanish without any trace. In this case these folk utterances with the researched component convey a metaphoric meaning of irrevocability, a lifelong loss: Кинув як у болото.

The internal form of the Ukrainian paroemias presents a swamp as a habitat of certain species of fauna such as a frog and a sandpiper. Furthermore, based on the mythological consciousness of the Ukrainian native speakers it acts as a place, inhabited by evil forces, in particular devils. The above mentioned zoonyms as well as lexemes "devil" and "swamp" are negatively evaluated, symbolyzing unconscientious, indecent people (a frog, a devil) who are always eager to take advantage of some bad situation in their favour: Аби болото, а жаби будуть. Another proverb В болоті не без чорта sounds as a testimony that there are always initiators of evil deeds.

In combination with the verbs denoting movement this component is a metaphor for immoral behavior, unhealthy lifestyle, bad influence: Видющий у болото не влізе, Срібло-золото тягне чоловіка в болото.

In the Ukrainian linguoculture a swamp symbolizes moral impurity and petty material interests in contrast with high spirituality, hence, a swamp conveys a metaphoric meaning of gossips, aspender, quarrels: Де велика глота, там много болота; Не міси болота!, i.e. "Don't spread rumours".

One can also find proverbs composed on the contrast of "gold" and "swamp" which correlate with the archetypal opposition good-evil, as well as precious-unprecious: Людям як болото, а матері як злото. Interrelation devil-swamp is included in the structure of the proverbs which are built on the comparison of such similar negative phenomena as a devil in the swamp and a drunkard in the village/family: В болоті не без чорта, в сім'їне без п'яниці.

A great number of paremiological units containing the lexeme "болото" are aimed at depiction of human personality and behaviour. They condemn such traits of character as arrogance: Насміхавсь кулик болоту, та й сам ж туди у воду; obtrusiveness: Вчепився мене, як біда 
болота; obstinacy, hypocrisy: Другим дорогу показує, а сам болото бриде; greediness, excessive desire for enrichment: I чорт багато громей має, а в болоті сидить; idleness: Свиню легше вигнати з болота, ніж ледаря на роботу; unreliableness: 3 ним не виведе справи і той, що у болоті; impudence: Сидить, як чорт на громах в болоті; austerity, unfair treatment of others: Править як чорт болотом; self-conceit: Коли свиня в болоті, то мовить, щьо красна.

Conclusions. The concept болото is crucial in the common consciousness of the Ukrainians, which is proved by the diverse reflection of this image in the paremiological view of the world and a large number of paroemias with the name of this landscape object. However, all the proverbially verbalized meanings are extremely negatively marked, which is predetermined by the ancient demonic philosophy of the Ukrainians, who associated marshy land with impure forces, thus making everything which relates to this element of relief negative. The English paremiological corpus, on the contrary, lacks paroemias containing the name "swamp" or its equivalents, which, however, does not devalue the importance of this concept for the Englishmen, as the lexeme "swamp" is characterized by the productive synonymous row. The common ethnocultural meanings of the compared paroemias in both languages are: a habitat of some species of birds, amphibians; a favourite place for particular domestic animals, metaphoric meaning "far", "in the distance".

\section{REFERENCES}

1. Енциклопедія сучасної України. Інститут енциклопедичних досліджень НАН України. 2014-2019. Retrieved from https://esu.com.ua/search_articles.php?id=51456.

2. Лановик М. Б. Українська усна народна творчість. Підручник. - К. 2005. 3. 591.

3. Словник української мови в 11-и томах. 1970-1980. Retrieved from https://sum.in.ua/s/boloto.

4. The free dictionary by Farlex. Retrieved from https://www.thefreedictionary.com/swamp. 